\title{
Effect of Some Bioagents on Cladosporium cucumerinum Causing Cladosporium Leaf Spot: A New Challenge in Watermelon Production in Egypt.
}

Farag, M.F ${ }^{1}$ and Aref, E.M. ${ }^{2}$

1- Plant Pathology Research Institute, Agricultural Research Center, Giza, Egypt.

2- Soils, Water and Environment Research Institute, Agricultural Research Center, Giza, Egypt.

Geven isolates of bioagents, Trichoderma harzianum, Pseudomonas Stuorescens, Bacillus subtilis, Anabena oryzae, Nostoc muscorum, Chaetomium globosum and Gliocladium catenulatum were used to control cladosporium leaf spot. Nostoc muscorum mixed with Pseudomonas fluorescens successfully reduced the growth and spore germination of Cladosporium cucumerinum. The potentially of the bioagents significantly reduced the cladosporium leaf spot disease incidence and inhibiting its progress when used each alone or as mixtures under field conditions. The bioagents generally improved the watermelon plants and significantly increased the plant height, number of branches, fruit numbers and fruits weight due to treatment with the tested bioagents either each alone or in mixture compared to the untreated control.

Keywords: bio-agents, Trichoderma harzianum, Pseudomonas fluorescens, Cladosporium cucumerinum, leaf spot, watermelon

Watermelon (Citrullus lanatus) is considered as fruited crop belonging to the family Cucurbitaceae (Edwards et al., 2003), and is considered one of the most important vegetable crops in Egypt. It is an annual creeping, commercial crop grown throughout the world as it is sugary, fleshy edible fruit. It is eaten especially during hot seasons (Bharath et al., 2005). Watermelon contains high levels of lycopene that is very effective in protect cells from damage and lower the risk of heart disease. Watermelon extracts help to reduce hypertension and lower blood pressure in obese adults. Watermelon fruit is also a good source of potassium. Potassium is an important component of cell and body fluids that helps controlling heart rate and blood pressure. Consequently, it prevents against stroke and coronary heart diseases (Le et al., 2005). Lycopene is an inhibitor for various inflammatory processes and also works as an antioxidant to neutralize free radicals. It also contains a good amount of vitamin-B6 (pyridoxine), vitamin-C and manganese. Consumption of food rich in vitamin-C helps the body to develop resistance against infectious agents 
and scavenge harmful oxygen-free radicals. Manganese is used by the body as a cofactor for the antioxidant enzyme, superoxide dismutase.

Watermelon is an excellent source of Vitamin A, which is a powerful natural antioxidant. It is one of the essential vitamins for vision and immunity (Edwards et al., 2003).

Cladosporium leaf spot was recorded in Egypt as the first report in 2018 on watermelon plants. Cladosporium cucumerinum is the causal pathogen of this disease lesions were observed on leaves and petioles brown to dark brown in color with or without a chlorotic halo. Shape of lesions was circular to oval and on leaves they were generally 1 to $14 \mathrm{~mm}$ in diameter. The conidia measured 2 to $8 \times 1$ to 3 $\mu \mathrm{m}$ (average $4.94 \times 1.94 \mu \mathrm{m}$ ) (Farag, 2018).

Chemicals have played an important role in manage the diseases management in various vegetable crops over the years. Due to the excessive use of fungicides, the cost of crop production has also increased. Fungicides are toxic in nature and are equally harmful to human beings if applied injudiciously (Abhilash and Singh 2009). However, the continuous use of chemical fungicides led to the development of resistance in pests and residue in food chains and effect on human health and environment have been realized. Biological control may offer a good substitute to fungicides. Fungal and bacterial antagonists are one of the chief biological agents that have been studied for the control of foliar diseases (Hussein et al., 2007; Zegeye et al., 2011 and Abo-Elyousr et al., 2017). Bio-control agents such as C. globosum, G. catenulatum, T. harzianum, B. subtilis, and P. fluorescens have the ability to control cladosporium leaf spots (Huang 1978; Xiao and Li. 2013; Sandoval, et al., 2009 and Wang et al., 2018) and enhance the plant growth (Compant et al., 2005).

Various strains of cyanobacteria such as Nostoc muscorum and Anabaena oryzae are known to produce intracellular and extracellular metabolites with diverse biological activities such as antibacterial, antifungal and antiviral activity. These biologically active compounds include antibiotics and toxins (De Caire et al., 1990; Abo-Shady et al., 2007 and Abedin \& Taha, 2008.). This study was promised to evaluate the potential of C. globosum, G. catenulatum, T. harzianum, P. fluorescens, B. subtilis, and various strains of cyanobacteria such as Nostoc muscorum and Anabena oryzae when they were used each alone or in mixture to control leaf spot on watermelon and improvement its productivity using two application methods: seed soaking and/or foliar spray under field conditions.

\section{Materials and Methods}

Seven bio-agents isolates representing in Trichoderma harzianum, Pseudomonas fluorescens, Bacillus subtilis, Anabena oryzae and Nostoc muscorum were kindly obtained from the Department of Microbiology, Soil, Water \& Environment Res. Inst., ARC, Giza, Egypt in addition to Chaetomium globosum and Gliocladium

Egypt. J. Phytopathol., Vol. 47, No. 1 (2019) 
catenulatum, isolated during this study from watermelon leaves and identified at Assiut University Mycological Center based on their morphological characteristics were cultured and maintained on potato dextrose agar (PDA). All these bioagents were used each alone or in mixtures to evaluate their potential on Cladosporium cucumerinum spore germination, the antagonistic effect on $C$. cucumerinum growth in vitro as well as to control cladosporium leaf spot on watermelon and to improve its productivity using two application methods: seeds soaking and/or foliar spray under field conditions.

Bacterial suspension of $B$. subtilis was grown in nutrient broth medium for multiplication, while P. fluorescens was multiplied on King B (KB) liquid medium (King et al., 1954) using shaking flask submerged culture, where $500 \mathrm{ml}$ conical flasks, each containing $200 \mathrm{ml}$ of the respective media was inoculated by one $\mathrm{ml}$ bacterial inoculum of $24 \mathrm{~h}$ old culture and incubated in rotary shaking incubator $(120 \mathrm{rpm})$ at $25 \pm 1^{\circ} \mathrm{C}$ for $48 \mathrm{~h}$. Chaetomium globosum and Gliocladium catenulatum were grown on potato dextrose broth medium. T. harzianum was grown in Trichoderma-selective medium broth (TSM) (Elad et al., 1981), amended with streptomycin and $50 \mu \mathrm{g} \mathrm{ml}^{-1}$ rose Bengal in conical flask, incubated at $25^{\circ} \mathrm{C}$ for 15 days

The effect of tested cyanobacteria on linear growth of $C$. cucumerinum:

The effect of $N$. muscorum and A. oryzae against the growth of Cladosporium cucumerinum was determined using a linear growth method. Dry N. muscorum and A. oryzae $(0.03 \mathrm{~g})$ were added to melted, autoclaved PDA medium. About $15 \mathrm{ml}$ of the medium were poured into each Petri dish and allowed to solidify. Inocula $(5 \mathrm{~mm})$ taken from a 7-day-old culture of C. cucumerinum were placed in the center of the prepared Petri dishes. For the other tested bioagents (fungi and bacteria), a $5 \mathrm{~mm}$ disk was taken from the growth of each antagonistic fungus and/or bacterium and was placed onto the PDA, $10 \mathrm{~mm}$ from the edge of the Petri dish and $5 \mathrm{~mm}$ disc from $C$. cucumerinum was placed on the opposite side and then incubated for seven days at $25 \pm 2 \circ \mathrm{C}$. PDA medium without the cyanobacterial filtrates, fungal and bacterial tested served as control (Singh \& Tripathi, 1999). Both experimental and control dishes were assigned to a completely randomized design, with five replicates per treatment. The antagonistic effect measurements were carried out when the pathogenic fungal growth filled all Petri dishes in control. The effect of the cyanobacterial filtrates and bioagents growth in terms of percentage inhibition of mycelial growth was calculated using the formula:

$$
\text { Reduction in linear growth }=[(\mathrm{C}-\mathrm{T}) / \mathrm{C}] \times 100
$$

Where: $\mathrm{C}=$ growth of $C$. cucumerinum on control, $\mathrm{T}=$ growth of $C$. cucumerinum with cyanobacterial extracts and bioagents. 
Effect of the tested bioagents on spore germination of C. cucumerinum:

Drops of the tested bioagents suspension were placed separately or in mixture on glass slides and spore suspension drops of C. cucumerinum were placed exactly on these respective drops. These slides were kept in Petri plates lined with moist blotting paper and then placed in moist chamber. Spores immersed in distilled water as well as fungicide suspension (Ridomil gold MZ $68 \mathrm{WG}$ ) served as control. Three replicates were made for each treatment. The slides were incubated at $25 \pm 2^{\circ} \mathrm{C}$ for 24 $\mathrm{h}$ and the percent of germination was calculated under a light microscope.

\section{Field experiments:}

Two application methods: seeds soaking and foliar spray/or just foliar spray only under field experimental conditions were carried out at the farm of Agricultural Research of Sids Station, Agric. Res. Center, Beni Sweif governorate, during early summer growing seasons (from middle of February to April 2018 to 2019) to evaluate the potential of Bacillus subtilis, Pseudomonas fluorescens $\left(3 \times 10^{8} \mathrm{cfu}\right)$, Chaetomium globosum, Gliocladium catenulatum, Trichoderma harzianum $\left(3 \times 10^{6}\right.$ conidia per ml) and cyanobacteria (Nostoc muscorum and Anabena oryzae, 50 $\mathrm{L} / \mathrm{Fed}$.), each alone or in mixture to control cladosporium leaf spot on watermelon and increasing its productivity.

Field design and soil analysis:

The soil of the experimental field was clay in texture $(16.5 \%$ sand, $30.1 \%$ silt, $53.4 \%$ clay), $\mathrm{pH}$ of 8.1, EC $1.2 \mathrm{dSm}^{-1} ; 1.3 \%$ organic matter and 26.2, 10.1 and $176 \mathrm{ppm}$ available $\mathrm{N}, \mathrm{P}$ and $\mathrm{K}$, respectively. The experiment was set in a randomized complete blocks design with two factors, three replications for each treatment. The first factor was assigned to the bioagents tested and the second one to application methods. The field plots were $6 \times 3.5 \mathrm{~m}$.

\section{Field Preparation:}

In each season, the soil was mechanically plowed and planked twice prepared into ridges $(2 \mathrm{~m}$ width). During the preparation for cultivation, calcium superphosphate $\left(15.5 \% \mathrm{P}_{2} \mathrm{O}_{5}\right)$ as a source of phosphorus was added in the rate of 200 $\mathrm{kg} / \mathrm{fed}$. The watermelon seeds (Giza 1 cultivar) were soaked in the bioagents suspension for $24 \mathrm{~h}$ and the treated and untreated seeds were sown at $75 \mathrm{~cm}$ spacing between plants on February $15^{\text {th }}$ in the two experimental seasons. Weeds were removed by manual operations as needed and plants were irrigated regularly as necessary, throughout the growing season to maintain constant growth. Nitrogen was applied in the form of ammonium nitrate $(33 \% \mathrm{~N})$, at the rate of $400 \mathrm{~kg} / \mathrm{fed}$. (recommended rate). Potassium sulfate $\left(48 \% \mathrm{~K}_{2} \mathrm{O}\right)$ as a source of potassium was added at the rate of $75 \mathrm{~kg} / \mathrm{fed}$. The plants were sprayed every 10 days, always performed early in the morning, with the tested bioagents, $1 \%$ Tween 20 as well as the fungicide Ridomil gold MZ $68 \mathrm{WG}$ at the rate of $50 \mathrm{gm} / 100 \mathrm{~L}$ water before the appearance of first symptoms until run off and distilled water (control). Monitoring

Egypt. J. Phytopathol., Vol. 47, No. 1 (2019) 
and scouting the plants weekly for the appearance of cladosporium leaf spot and disease incidence and severity were estimated as follow:

Disease assessment:

Percentage of disease incidence was recorded as the number of diseased plants relative to the number of growing plants for each treatment and then the average of disease incidence was calculated. Disease severity (DS) was recorded using the following 0 to 5 scale: 0 , no incidence; 1 , lesions limited to lower $1 / 5$ of leaf area; 2 , lesions present on lower $1 / 3$ of leaf area; 3 , lesions present on more than $1 / 3$ of leaf area; 4 , lesions present on more than $2 / 3$ of leaf area; and 5, severe infections on all leaves determined using the following formulas Shi et al. (2012):

$$
\text { DS }(\%)=\frac{\sum \text { disease scale } \times \text { number of leaves }}{\text { The most serius disease scale } \times \text { total number of leaves }} \times 100
$$

Evaluation of watermelon yield and its components:

Plant length $(\mathrm{m})$, branches numbers/plant, fruits number/plant and fruits weight/plant $(\mathrm{kg})$ were determined as averages from the replicates.

Evaluation total phenols and growth hormones:

Total phenols was estimated using Folin ciocalteau reagent method described by Lafka et al. (2007). Plant hormones (abscisic acid, gibberellic acid and indole acetic acid) were determined according to the method described by (Shindy and Smith, 1975).

Data were statistically analyzed for computing L.S.D. test at $5 \%$ probability according to the procedure outlined by Snedecor and Cochran (1989).

\section{Res u l t s}

The effect of tested bioagents on spore germination and linear growth of $C$. cucumerinum:

In the antagonism experiments, clear inhibition zones on the PDA plates were observed, and the mycelium of $C$. cucumerinum stopped growing confronted to $A$. oryzae, B. subtilis, C. globosum, G. catenulatum, N. muscorum, P. fluorescens, $T$. harzianum and their combinations after 7-10 days of incubation (Table, 1). Treatment of $N$. muscorum mixed with $P$. fluorescens recorded the highest reduction in linear growth $(83.3 \%)$ and spore germination of $C$. cucumerinum $(82.7 \%)$. followed by $N$. muscorum mixed with T. harzianum (76.7 and 80.8\%), N. muscorum mixed with $B$. subtilis (75.6 and $81.4 \%$ ) and A. oryzae mixed with $P$. fluorescens $(73.3$ and $80.5 \%)$ treatments with no significant differences among them except with treatment of $A$. oryzae $+P$. fluorescens in case of linear growth. In general, the fungicide Ridomil gold MZ 68 WG was more effective than the other treatments in reducing the linear growth $(91.1 \%)$ and spore germination $(88.6 \%)$ of $C$. cucumerinum. On the other hand, $C$. globosum recorded the lowest effect on the linear growth reduction and spore germination, being 38.9 and $69.7 \%$.

Egypt. J. Phytopathol., Vol. 47, No. 1 (2019) 
Table (1): Effect of different bioagents on spore germination and linear growth of C. cucumerinum in vitro

\begin{tabular}{|l|c|c|c|c|}
\hline \multicolumn{1}{|c|}{ Treatments } & $\begin{array}{c}\text { Germination } \\
\%\end{array}$ & $\begin{array}{c}\text { Reduction* } \\
\%\end{array}$ & $\begin{array}{c}\text { Linear } \\
\text { growth }\end{array}$ & $\begin{array}{c}\text { Reduction* } \\
\%\end{array}$ \\
\hline A. oryzae & 8.8 & 76.2 & 3.4 & 62.2 \\
\hline B. subtilis & 9.3 & 74.9 & 4.5 & 50.0 \\
\hline C. globosum & 11.2 & 69.7 & 5.5 & 38.9 \\
\hline G. catenulatum & 10.5 & 71.6 & 4.8 & 46.7 \\
\hline N. muscorum & 8.7 & 76.5 & 3.2 & 64.4 \\
\hline P. fluorescens & 9.2 & 75.1 & 3.8 & 57.8 \\
\hline T. harzianum & 9.7 & 73.8 & 5.0 & 44.4 \\
\hline A. oryzae + B. subtilis & 8.3 & 77.6 & 2.9 & 67.8 \\
\hline A. oryzae $+P$. fluorescens & 7.2 & 80.5 & 2.4 & 73.3 \\
\hline A. oryzae + T. harzianum & 8.2 & 77.6 & 2.5 & 72.2 \\
\hline N. muscorum + B. subtilis & 6.9 & 81.4 & 2.1 & 75.6 \\
\hline N. muscorum + P. fluorescens & 6.4 & 82.7 & 1.5 & 83.3 \\
\hline N. muscorum + T. harzianum & 7.1 & 80.8 & 2.2 & 76.7 \\
\hline Ridomil gold MZ 68 WG & 4.2 & 88.6 & 0.8 & 91.1 \\
\hline Control & 37.0 & ---- & 9.0 & ---- \\
\hline L.S.D. at 0.05 & 0.9 & ---- & 0.4 & ---- \\
\hline
\end{tabular}

* Reduction \% related to the control.

The effect of tested bioagents on disease incidence and severity:

Data in Tables ( 2 and 3) focus on the potentialities of the bioagents to reduce significantly the cladosporium leaf spot disease incidence and inhibit the progress of disease compared with the untreated control (Fig.1) when they were used individually or as mixtures under field conditions. Among all treatments, the fungicide Ridomil gold MZ 68 WG was the most efficient in this regard which recorded the lowest disease incidence, being $16.8,13.4$ and $7.9 \%$, respectively and significantly delayed the progress of disease to $9.8,6.7$ and $3.9 \%$, respectively as a result of the three sprays. Nostoc muscorum mixed with $P$. fluorescens came in the second rank and recorded the best value on reducing disease incidence and severity followed by $N$. muscorum mixed with $B$. subtilis without significant differences between them. The corresponding mean values in disease incidence were 19.2, 15.4, $13.5 \& 20.1,16.9,14.5 \%$, respectively and $12.1,7.8,4.8 \% \& 12.4,8.8,5.2$, respectively for disease severity. Moderate disease incidence and severity were observed in plots received A. oryzae mixed with P. Fluorescens and N. muscorum mixed with $T$. harzianum without significant differences between them followed by $A$. oryzae mixed with $B$. subtilis and $A$. oryzae mixed with $T$. harzianum treatments. Meanwhile, treatment of C. globosum was the least effective in this concern. Overall

Egypt. J. Phytopathol., Vol. 47, No. 1 (2019) 
the method of seed soaking and spraying the watermelon plants with the tested bioagents was the best method to reduce the incidence and severity of cladosporium leaf spot.

The interaction effect of the different bioagent treatments and their application methods was significant during the two successive growing seasons. The lowest values of disease incidence $(15.5,13.2 \& 6.3 \%$, respectively) and disease severity (9.4, $5.5 \& 3.3 \%$, respectively) were obtained due to treatment with fungicide Ridomil gold MZ 68 WG as watermelon seeds soaking and foliar spray followed by treatment of $N$. muscorum $+P$. fluorescens when applied as seed soaking and foliar spray. While the lowest efficient was $C$. globosum treatment when applied as foliar spray only.

Table (2): Effect of bioagents on disease incidence \% of cladosporium leaf spot at the average of two successive growing seasons 2018/2019.

\begin{tabular}{|c|c|c|c|c|c|c|c|c|c|}
\hline \multirow{5}{*}{$\begin{array}{c}\text { Treatments } \\
\text { (T) }\end{array}$} & \multicolumn{9}{|c|}{ Disease incidence $\%$} \\
\hline & \multicolumn{9}{|c|}{ Mean of the two growing seasons } \\
\hline & \multicolumn{9}{|c|}{ Application methods (M) } \\
\hline & \multicolumn{3}{|c|}{$1^{\text {st }}$ spray } & \multicolumn{3}{|c|}{$2^{\text {nd }}$ spray } & \multicolumn{3}{|c|}{$3^{\text {rd }}$ spray } \\
\hline & 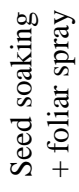 & 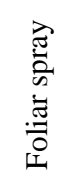 & $\underset{\Xi}{\stackrel{E}{E}}$ & 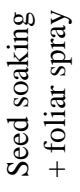 & 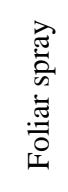 & $\underset{\underset{\Xi}{E}}{\stackrel{\Xi}{E}}$ & 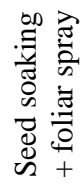 & 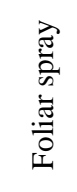 & 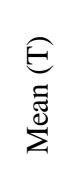 \\
\hline A. oryzae & 24.8 & 26.2 & 25.5 & 22.7 & 24.2 & 23.5 & 17.7 & 20.0 & 18.9 \\
\hline B. subtilis & 26.1 & 28.9 & 27.5 & 22.8 & 25.3 & 24.1 & 19.2 & 20.7 & 20.0 \\
\hline C. globosum & 30.0 & 32.7 & 31.4 & 26.5 & 29.5 & 28.0 & 21.6 & 24.0 & 22.8 \\
\hline G. catenulatum & 27.7 & 29.5 & 28.6 & 23.7 & 26.9 & 25.3 & 19.9 & 21.8 & 20.9 \\
\hline N. muscorum & 24.0 & 25.8 & 24.9 & 21.6 & 23.8 & 22.7 & 16.9 & 19.2 & 18.1 \\
\hline P.fluorescens & 25.5 & 28.3 & 26.9 & 22.7 & 25.3 & 24.0 & 18.6 & 20.8 & 19.7 \\
\hline T. harzianum & 27.1 & 29.1 & 28.1 & 23.6 & 25.7 & 24.7 & 19.8 & 21.8 & 20.8 \\
\hline A. oryzae + B. subtilis & 21.7 & 23.4 & 22.5 & 17.1 & 19.0 & 18.1 & 14.3 & 15.7 & 15.0 \\
\hline A. oryzae $+P$. fluorescens & 19.8 & 21.2 & 20.5 & 16.7 & 18.6 & 17.7 & 13.7 & 16.2 & 15.0 \\
\hline A. oryzae $+T$. harzianum & 23.1 & 25.3 & 24.2 & 19.0 & 22.6 & 19.7 & 15.4 & 17.7 & 16.5 \\
\hline N. muscorum + B. subtilis & 19.6 & 20.6 & 20.1 & 16.1 & 17.6 & 16.9 & 13.7 & 15.2 & 14.5 \\
\hline N. muscorum + P. fluorescens & 18.7 & 19.7 & 19.2 & 14.5 & 16.3 & 15.4 & 10.9 & 14.1 & 13.5 \\
\hline N. muscorum + T. harzianum & 20.0 & 21.4 & 20.7 & 16.5 & 19.9 & 18.2 & 14.5 & 15.4 & 15.0 \\
\hline Ridomil gold MZ 68 WG & 15.5 & 18.9 & 17.2 & 13.2 & 15.5 & 14.5 & 6.3 & 11.2 & 8.8 \\
\hline Control & 36.6 & 35.1 & 35.9 & 53.5 & 48.0 & 50.8 & 61.3 & 60.9 & 61.1 \\
\hline Mean $(\mathrm{M})$ & 24.0 & 25.7 & --- & 22.0 & 23.9 & --- & 18.9 & 21.0 & --- \\
\hline L.S.D. at 0.05 & \multicolumn{3}{|c|}{$\begin{array}{c}\mathrm{T}=1.0 \mathrm{M}=0.4 \\
\mathrm{TM}=1.4\end{array}$} & \multicolumn{3}{|c|}{$\begin{array}{c}\mathrm{T}=1.1 \mathrm{M}=0.4 \\
\mathrm{TM}=1.6\end{array}$} & \multicolumn{3}{|c|}{$\begin{array}{c}\mathrm{T}=1.5 \mathrm{M}=0.6 \\
\mathrm{TM}=2.2\end{array}$} \\
\hline
\end{tabular}


Table (3): Effect of bioagents on disease severity \% of cladosporium leaf spot at the average of two successive growing seasons 2018/2019.

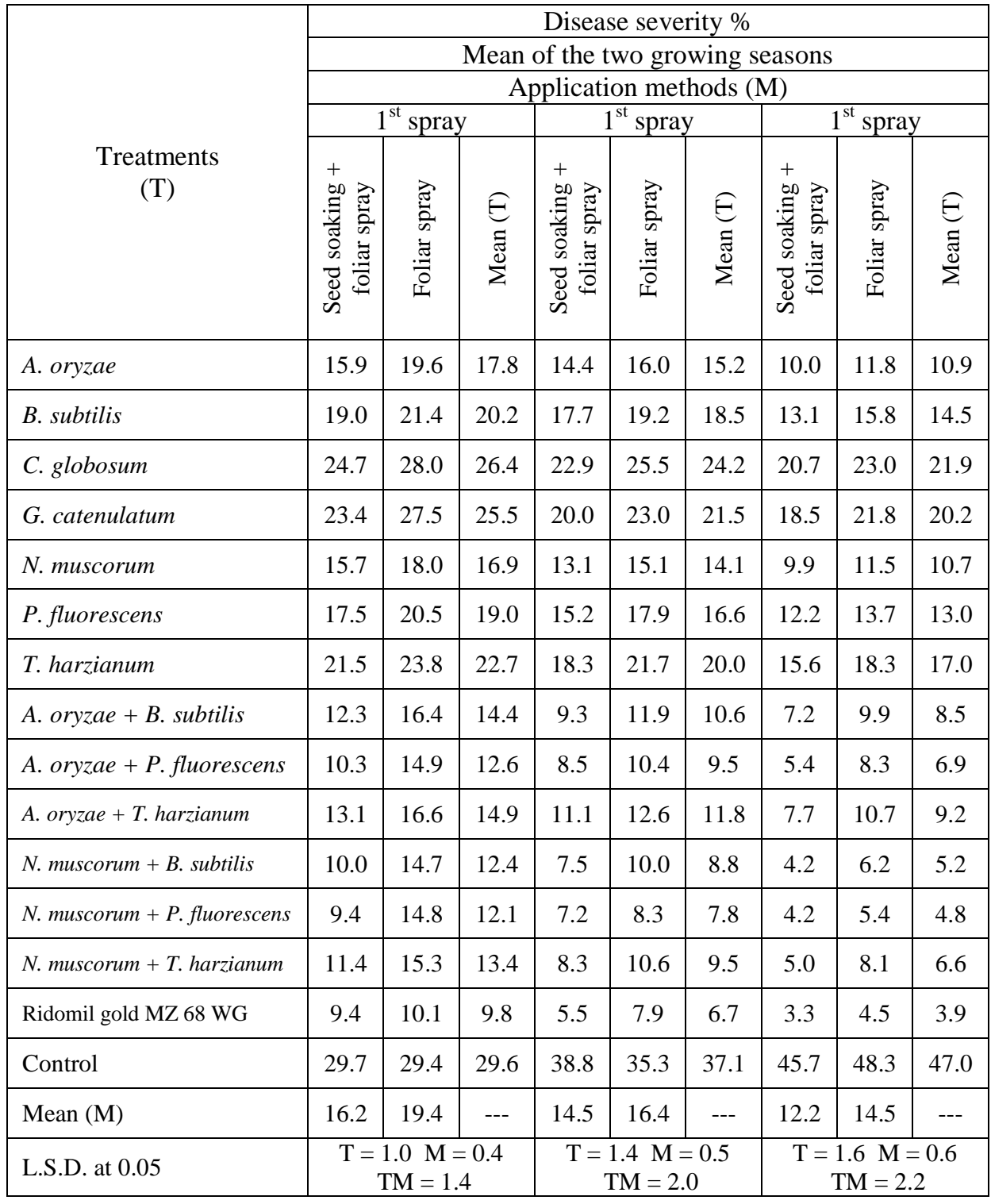

Egypt. J. Phytopathol., Vol. 47, No. 1 (2019) 


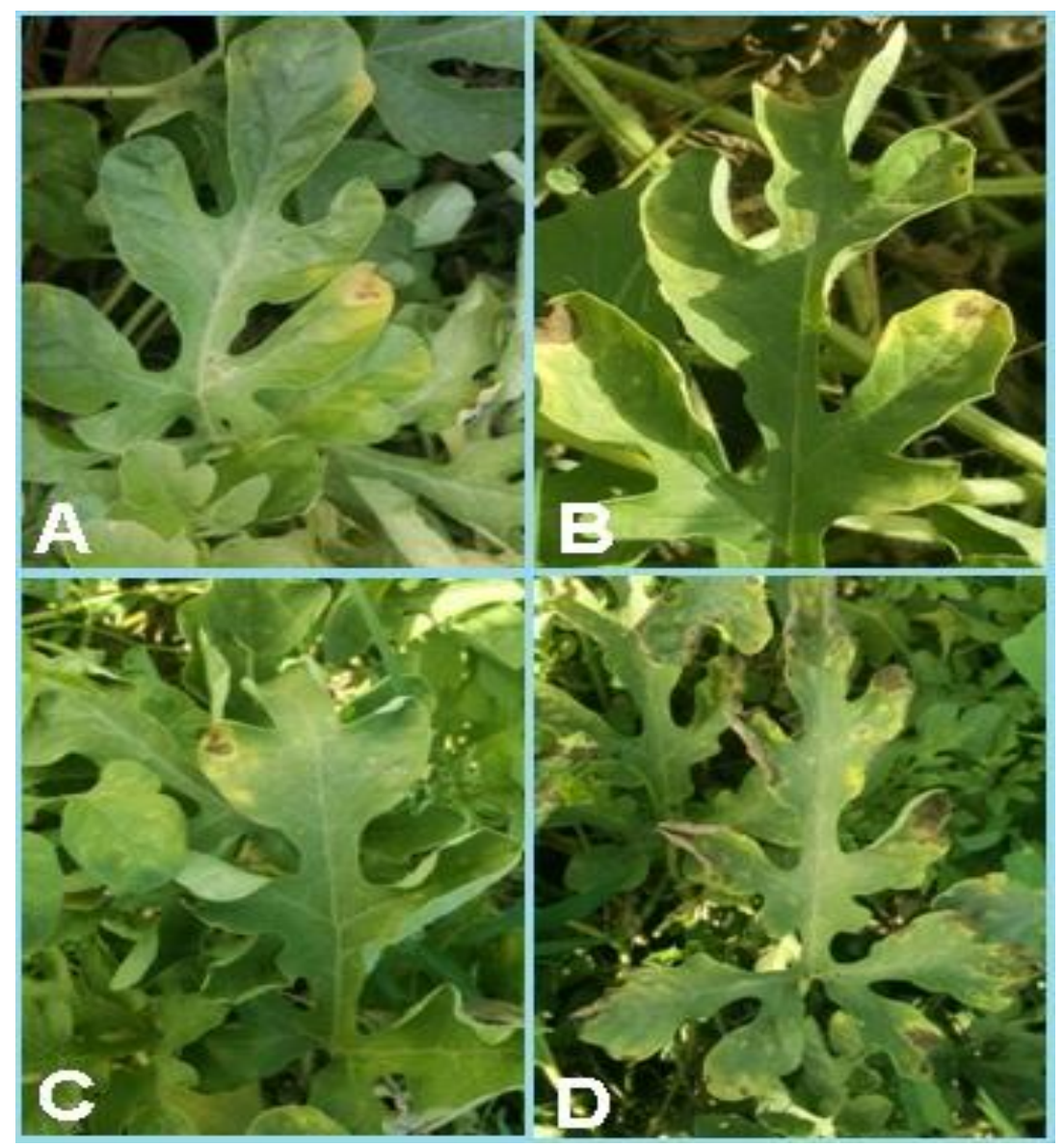

Fig. 1: Effect of some bioagents on cladosporium leaf spot, A; N. muscorum $+P$. fluorescens, B; N. muscorum + B. subtilis and $\mathrm{C} ; \mathrm{N}$. muscorum $+\mathrm{T}$. harzianum compared with control D

Effect of some biocontrol agents on some plant growth parameters:

Data presented in Tables, (4 and 5) show a general improvement in watermelon plants. Plant parameters (plant length $(\mathrm{m})$, number of branches/plant, fruits number/plant and fruits weight/plant $(\mathrm{kg})$ ) were significantly increased, due to treatment with the tested bioagents when used either each alone or in combination compared to the untreated control. Combined treatment between $N$. muscorum and $P$. fluorescens gave the highest values in these parameters followed by the combined treatment between $N$. muscorum and $B$. subtilis without significant differences between them. The corresponding mean values were $4.7 \& 4.5 \mathrm{~m}$, respectively for 
plant length; $17.0 \& 15.7$, respectively for branches number/plant; $3.7 \& 3.7$, respectively for fruits number/plant and $25.7 \& 23.2 \mathrm{~kg}$, respectively for fruits weight/plant. Moderate values were recorded with $A$. oryzae $+P$. fluorescens treatment followed by $N$. muscorum $+T$. harzianum treatment without significant differences between them. The lowest values were recorded with $C$. globosum treatment which recorded $2.7 \mathrm{~m}, 8.1,2.4$ and $15.6 \mathrm{~kg}$, respectively. Generally, watermelon seed soaking and spraying the leaves with the tested bioagents caused a significant promotion to plant growth and increased the yield than the spraying method only.

Table (4): Effect of some biocontrol agents on some plant growth parameters at the average of two successive growing seasons 2018/2019.

\begin{tabular}{|c|c|c|c|c|c|c|}
\hline \multirow[b]{4}{*}{$\begin{array}{l}\text { Treatments } \\
\quad(\mathrm{T})\end{array}$} & \multicolumn{6}{|c|}{ Mean of the two growing seasons } \\
\hline & \multicolumn{6}{|c|}{ Application methods (M) } \\
\hline & \multicolumn{3}{|c|}{ Plant length (m) } & \multicolumn{3}{|c|}{$\begin{array}{c}\text { Branches } \\
\text { number/plant }\end{array}$} \\
\hline & 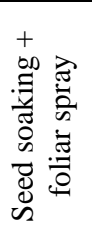 & 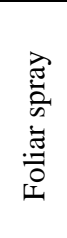 & $\begin{array}{l}\widehat{E} \\
\underset{\Xi}{\Xi} \\
\sum^{\infty}\end{array}$ & 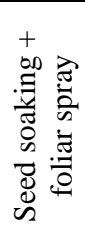 & 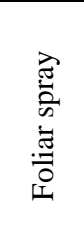 & 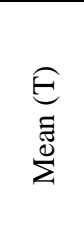 \\
\hline A. oryzae & 4.0 & 3.8 & 3.9 & 9.8 & 9.6 & 9.7 \\
\hline B. subtilis & 3.5 & 3.3 & 3.4 & 12.8 & 12.3 & 12.6 \\
\hline C. globosum & 2.8 & 2.4 & 2.6 & 9.2 & 6.9 & 8.1 \\
\hline G. catenulatum & 2.8 & 2.6 & 2.7 & 9.6 & 9.3 & 9.5 \\
\hline N. muscorum & 4.0 & 3.9 & 4.0 & 12.4 & 12.2 & 12.3 \\
\hline P. fluorescens & 3.7 & 3.4 & 3.6 & 12.2 & 9.6 & 10.9 \\
\hline T. harzianum & 3.7 & 3.2 & 3.5 & 9.8 & 9.6 & 9.7 \\
\hline A. oryzae + B. subtilis & 4.4 & 4.0 & 4.2 & 12.9 & 12.7 & 12.8 \\
\hline A. oryzae + P. fluorescens & 4.6 & 4.0 & 4.3 & 15.6 & 15.1 & 15.4 \\
\hline A. oryzae + T. harzianum & 4.1 & 3.9 & 4.0 & 12.6 & 12.1 & 12.4 \\
\hline N. muscorum + B. subtilis & 4.7 & 4.3 & 4.5 & 15.7 & 15.6 & 15.7 \\
\hline$N$. muscorum $+P$. fluorescens & 4.8 & 4.6 & 4.7 & 18.1 & 15.9 & 17.0 \\
\hline N. muscorum + T. harzianum & 4.5 & 3.9 & 4.2 & 15.1 & 15.0 & 15.1 \\
\hline Ridomil gold MZ 68 WG & 2.6 & 2.6 & 2.6 & 9.0 & 9.0 & 9.0 \\
\hline Control & 1.6 & 1.6 & 1.6 & 9.0 & 9.0 & 9.0 \\
\hline Mean $(\mathrm{M})$ & 3.7 & 3.4 & ---- & 12.3 & 11.6 & --- \\
\hline L.S.D. at 0.05 & \multicolumn{3}{|c|}{$\begin{array}{c}\mathrm{T}=0.4 \mathrm{M}=0.1 \mathrm{TM}= \\
0.5\end{array}$} & \multicolumn{3}{|c|}{$\begin{array}{c}\mathrm{T}=0.5 \mathrm{M}=0.2 \mathrm{TM}= \\
0.7\end{array}$} \\
\hline
\end{tabular}

Egypt. J. Phytopathol., Vol. 47, No. 1 (2019) 
The interaction between the tested bioagents and their application methods had significant effect on the aforementioned parameters. The maximum values were obtained from plots received watermelon seeds soaked in a mixture of N. muscorum $+P$. fluorescens and spraying the leaves with their suspensions followed by $N$. muscorum $+B$. subtilis, A. oryzae $+P$. fluorescens treatments without significant differences among them except in fruits weight/plant. While the lowest values of plant height $(2.6 \mathrm{~m})$, branches number/plant (6.9), fruits number/plant (2.2) and fruits weight/plant $(15.1 \mathrm{~kg})$ were obtained from plots received C. globosum as foliar spray only compared to the other tested bioagents treatments.

Table (5): Effect of some biocontrol agents on fruits number/plant and fruits weight/plant at the average of two successive growing seasons 2018/2019.

\begin{tabular}{|c|c|c|c|c|c|c|}
\hline \multirow[b]{4}{*}{$\begin{array}{l}\text { Treatments } \\
\text { (T) }\end{array}$} & \multicolumn{6}{|c|}{ Mean of the two growing seasons } \\
\hline & \multicolumn{6}{|c|}{ Application methods (M) } \\
\hline & \multicolumn{3}{|c|}{ Fruits number/plant } & \multicolumn{3}{|c|}{ Fruits weight/plant } \\
\hline & 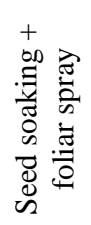 & 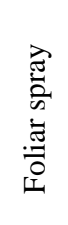 & $\begin{array}{l}\underset{\Xi}{\Xi} \\
\underset{\Sigma}{\Xi}\end{array}$ & 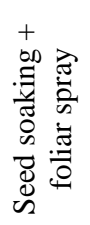 & 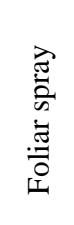 & 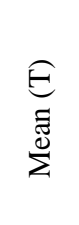 \\
\hline A. oryzae & 2.5 & 2.2 & 2.4 & 15.7 & 15.2 & 15.5 \\
\hline B. subtilis & 2.8 & 2.5 & 2.7 & 18.5 & 18.0 & 18.3 \\
\hline C. globosum & 2.5 & 2.2 & 2.4 & 15.7 & 15.1 & 15.4 \\
\hline G. catenulatum & 2.7 & 2.3 & 2.5 & 18.1 & 15.4 & 16.8 \\
\hline N. muscorum & 2.9 & 2.7 & 2.8 & 18.7 & 15.8 & 17.3 \\
\hline P. fluorescens & 2.9 & 2.7 & 2.8 & 18.0 & 15.5 & 16.8 \\
\hline T. harzianum & 2.8 & 2.6 & 2.7 & 18.3 & 18.2 & 18.3 \\
\hline A. oryzae + B. subtilis & 3.6 & 3.0 & 3.3 & 21.1 & 18.7 & 19.9 \\
\hline A. oryzae + P. fluorescens & 3.7 & 3.5 & 3.6 & 21.3 & 21.1 & 21.2 \\
\hline A. oryzae + T. harzianum & 2.8 & 2.7 & 2.7 & 18.7 & 18.5 & 18.6 \\
\hline N. muscorum + B. subtilis & 3.8 & 3.6 & 3.7 & 24.5 & 21.9 & 23.2 \\
\hline N. muscorum $+P$. fluorescens & 3.8 & 3.7 & 3.7 & 27.2 & 24.4 & 25.7 \\
\hline N. muscorum $+T$. harzianum & 3.4 & 3.2 & 3.3 & 21.3 & 21.1 & 21.2 \\
\hline Ridomil gold MZ 68 WG & 2.6 & 2.6 & 2.6 & 12.9 & 12.9 & 12.9 \\
\hline Control & 2.0 & 2.0 & 2.0 & 12.9 & 12.9 & 12.9 \\
\hline Mean $(\mathrm{M})$ & 3.0 & 2.8 & --- & 18.9 & 17.6 & --- \\
\hline L.S.D. at 0.05 & \multicolumn{3}{|c|}{$\mathrm{T}=0.4 \mathrm{M}=0.1 \mathrm{TM}=0.6$} & \multicolumn{3}{|c|}{$\mathrm{T}=0.6 \mathrm{M}=0.2 \mathrm{TM}=0.9$} \\
\hline
\end{tabular}


Evaluation of total phenols:

Data presented in Table, 6 show the effect of the tested bioagents on the total phenols in the treated watermelon plants compared to the untreated control. Generally, phenolic content in watermelon leaves revealed a reverse relationship with the degree of infection by the pathogen. When the mixture of bioagents was applied, the phenolic content of leaves was higher than using each treatment alone. Maximum increase was detected with $N$. muscorum mixed with $P$. fluorescens treatment, being 18.977 followed by treatment of $N$. muscorum mixed with $B$. subtilis, being 18.080 without significant differences between them. The lowest phenolic content was detected in watermelon plants treated with $C$. globosum followed by $G$. Catenulatum treatment without significant differences. The corresponding mean values were 0.992 and 1.313 , respectively. Soaking the watermelon seeds and spraying the leaves with bioagents suspensions significantly increased the phenolic content compared to spraying the leaves by any suspension only.

Table (6): Total phenols in watermelon plants as affected by different bioagents tested.

\begin{tabular}{|l|c|c|c|}
\hline \multirow{2}{*}{\multicolumn{1}{|c|}{ Treatments (T) }} & \multicolumn{3}{|c|}{ Total phenol } \\
\cline { 2 - 4 } & $\begin{array}{c}\text { Seed soaking } \\
\text { +foliar spray }\end{array}$ & Foliar spray & Mean (T) \\
\hline A. oryzae & 6.414 & 3.629 & 5.022 \\
\hline B. subtilis & 5.606 & 2.116 & 3.861 \\
\hline C. globosum & 1.111 & 0.872 & 0.992 \\
\hline G. catenulatum & 1.715 & 0.911 & 1.313 \\
\hline N. muscorum & 7.609 & 4.408 & 6.009 \\
\hline P. fluorescens & 6.062 & 2.527 & 4.295 \\
\hline T. harzianum & 4.411 & 2.076 & 3.244 \\
\hline A. oryzae + B. subtilis & 13.453 & 7.866 & 10.660 \\
\hline A. oryzae + P. fluorescens & 19.801 & 10.909 & 15.366 \\
\hline A. oryzae $+T$. harzianum & 12.591 & 7.710 & 10.151 \\
\hline N. muscorum + B. subtilis & 25.230 & 10.930 & 18.080 \\
\hline N. muscorum + P. fluorescens & 26.934 & 11.020 & 18.977 \\
\hline N. muscorum + T. harzianum & 16.776 & 9.033 & 12.905 \\
\hline Ridomil gold MZ 68 WG & 2.042 & 2.037 & 2.040 \\
\hline Control & 0.007 & 0.009 & 0.008 \\
\hline Mean (M) & 9.984 & 5.070 & --- \\
\hline L.S.D. at 0.05 & T=1.653 & M=0.604 & TM=2.338 \\
\hline
\end{tabular}

Egypt. J. Phytopathol., Vol. 47, No. 1 (2019) 
The interaction between bioagents treatments tested and their application methods had significant effect on total phenol. $N$. muscorum mixed with $P$. fluorescens showed the highest total phenol (26.934) followed by $N$. muscorum $+B$. subtilis (25.230) when applied as seed soaking and foliar spray treatment with significant differences between them while the lowest value was noticed when watermelon plants were sprayed with $C$. globosum treatment.

Evaluation of growth hormones:

Data presented in Table, 7 show the capabilities of the tested bioagents to produce phytohormones. It is worthy to note that; $N$. muscorum produced higher abscisic acid (ABA) than the other bioagents tested being, $5.23 \mu \mathrm{g} / \mathrm{ml}$. A. oryzae exhibited moderate performance $(1.75 \mu \mathrm{g} / \mathrm{ml})$. While the lowest value obtained with T. harzianum $(0.33 \mu \mathrm{g} / \mathrm{ml})$ compared with $0.55 \mu \mathrm{g} / \mathrm{ml}$ in B. subtilis treatment and $0.62 \mu \mathrm{g} / \mathrm{ml}$ in $P$. fluorescens treatment which lies in the same statistical group. In the case of Gibberellic acid (GA3), A. oryzae produced the highest amount (88.39 $\mu \mathrm{g} / \mathrm{ml})$ followed by $N$. muscorum $(28.59 \mu \mathrm{g} / \mathrm{ml})$ with significant differences between them. P. fluorescens significantly produced moderate gibberellic acid $(3.02 \mu \mathrm{g} / \mathrm{ml})$ higher than $B$. subtilis $(1.92 \mu \mathrm{g} / \mathrm{ml}))$ and $T$. harzianum $(1.50 \mu \mathrm{g} / \mathrm{ml})$ which statistically lies in the same group. On the other hand, $N$. muscorum produced indole acetic acid (IAA) higher than $A$. oryzae, being, 18.23 and $11.18 \mu \mathrm{g} / \mathrm{ml}$ respectively with significant differences between them. While $T$. harzianum produced lower indole acetic acid (IAA) than $B$. subtilis and $P$. fluorescens.

Table (7): Production of plant growth promoters by the tested bioagents.

\begin{tabular}{|l|c|c|c|}
\hline \multicolumn{1}{|c|}{ Bioagents } & $\begin{array}{c}\text { Abscisic acid } \\
(\mathrm{ABA})(\mu \mathrm{g} / \mathrm{ml})\end{array}$ & $\begin{array}{c}\text { Gibberellic acid } \\
(\mathrm{GA} 3)(\mu \mathrm{g} / \mathrm{ml})\end{array}$ & $\begin{array}{c}\text { Indole acetic acid } \\
(\mathrm{IAA})(\mu \mathrm{g} / \mathrm{ml})\end{array}$ \\
\hline A. oryzae & 1.75 & 88.40 & 11.18 \\
\hline B. subtilis & 0.55 & 1.92 & 7.03 \\
\hline N. muscorum & 5.23 & 28.59 & 18.23 \\
\hline P. fluorescens & 0.62 & 3.02 & 7.15 \\
\hline T. harzianum & 0.33 & 1.50 & 6.79 \\
\hline L.S.D. at 0.05 & 0.23 & 0.51 & 0.34 \\
\hline
\end{tabular}

\section{D i s c us s i on}

Many experiments have been undertaken to identify alternate management mech anism of mechanisms of plant pathogens instead of fungicides, as the fungicide have environmental pollution and may contribute to the production of fungicideresistant strains (Soria et al., 2012). In the present study, all the tested bioagents applied as seed treatment with foliar spray or as foliar spray only significantly reduced losses caused by cladosporium leaf spot on watermelon and increased its productivity compared to the control. Seed treatment of watermelon and spraying the leaves with bioagents suspensions was the most effective in reducing the disease 
incidence and severity than spraying the leaves by the suspensions only. Mixing the cyanobacteria Nostoc muscorum or Anabaena oryzae with the fungal and bacterial antagonistic was more effective compared to each treatment separately. Among them, mixed treatment, of cyanobacterium ( $N$. muscorum) and the bacteria $(P$. fluorescens) showed the highest efficacy in this concern followed by $N$. muscorum + $B$. subtilis and A. oryzae $+P$. fluorescens treatments. These results are in agreement with those reported by Abdel-Hafez et al. (2015), who reported that application of culture filtrates of $N$. muscorum reduced purple blotch disease severity of onion under greenhouse conditions. $N$. muscorum contained high concentrations of phenolic compounds $\left(145.0 \mathrm{mg} \mathrm{l}^{-1}\right)$ and alkaloids (378.12 $\mathrm{mg} \mathrm{l}^{-1}$ ) which are employed as natural defense mechanisms against pathogenic fungi (Zeeshan et al., 2010). Abdel-Hafez et al. (2015) showed that the most prevalent component in culture filtrates of $N$. muscorum was $\beta$-ionone. Indol alkaloid norharmane and $\alpha$-isomethyl ionone were the second most prevalent in N. muscorum which may confer antimicrobial effects on the culture filtrates. Anabaena sp. produced numerous secondary metabolites, toxins and other compounds as lipopeptides, amino acids, fatty acids. Among the lipopeptides, some of them have demonstrated cytotoxic, antitumoral, antiviral, antibiotic activity and some effects as herbicides and antifungal against pathogens (Patterson et al., 1994). Gnanamanickam et al. (1992) observed that seed treatment followed by two sprayings with $P$. fluorescens effectively controlled rice sheath blight disease and leaf spot of groundnut (Meena and Marimuthu, 2012). Paul and Sharma (2006) reported the production of two antibiotics - pyoluteorin and pyrrolnitrin by $P$. fluorescens, which inhibit the growth of Phytophthora capsici, the pathogen of root rot of black pepper. However, Bargabus et al. (2004) reported that the main mode of action of $P$. fluorescens includes induce systemic resistance in addition to the production of siderophores which contributed to suppression of pathogens (Mathiyazhagan et al., 2004). In this study, treatment of watermelon seeds with the tested bioagents induced significant protection against Cladosporium cucumerinum, the causal agent of watermelon leaf spot that supports the suggestion of systemic resistance and excluding the possibility of direct antagonism because of the spatial separation between rhizobacteria in the rhizosphere and pathogens in the phyloplane.

Bacillus produces siderophores in order to adhere to the surface of nonbiological biofilm formation, which makes the Bacillus secretes broad-spectrum resistance compounds to a certain extent and increases the spectrum resistance of plants (Höfte and Bakker, 2007). Asaka and Shoda, (1996) reported that B. subtilis secreted antibiotics iturin A and surfactin for controlling plant diseases and enhancing the expression of the chitinase promoter (Shali et al., 2017). The high chitinase activity might have resulted in lyses of invading fungal pathogens (Fernando et al., 2007). The present study demonstrated that phenolic contents of watermelon leaves of treated plants with the tested bioagents were higher than that of control. When the mixture of bioagents was applied, the phenolic content of

Egypt. J. Phytopathol., Vol. 47, No. 1 (2019) 
leaves was higher than the using each treatment alone. Comparison between the degree of infection by the pathogen and the corresponding phenolic content in watermelon leaves revealed a reverse relationship, i.e. when the phenolic content is high, the degree of infection is low. The phenolic compounds contribute to enhance the mechanical strength of host cell wall and inhibit the fungal growth; they are acting as fungi toxic. Trichoderma species have been recognized as biocontrol agents against several pathogens (Perazzolli et al., 2008 and Shoresh et al., 2010). The biocontrol ability of Trichoderma species is based on different mechanisms such as interference with pathogen's pathogenicity enzymes (Kapat et al., 1998), direct interaction with the pathogen through antibiosis or parasitism (Elad \& Freeman, 2002 and Howell, 2003) and activation of plant disease resistance (Korolev et al., 2008).

On the other hand results of this study showed a general improvement in both vegetative and fruits yield of watermelon due to treatment with the tested bioagents related to the control. The plant growth promoting rhizobacteria (PGPR) B. subtilis, $P$. fluorescens and the fungus (T. harzianum) in addition to cyanobacteria ( $N$. muscorum, A. oryzae) produced indole acetic acid and gibberellic acid that play a key role in improving growth of many plants when applied as biofertilizers, these findings are in agreement with those reported by Aref (2011). Haiquan et al. (2013) mentioned that the mechanisms of PGPR mediated enhancement of plant growth and yields in many crops are as follows: ability to produce 1-aminocyclopropane-1carboxylates(ACC) deaminase to reduce the level of ethylene in roots of the developed plants and thereby increasing the root length and growth; ability to produce hormones like indole acetic acid, gibberellic acid and cytokinins; asymbiotic nitrogen fixation; solubilization of mineral phosphates and mineralization of other nutrients and control of phytopathogenic microorganisms. Asad and Vafa (2011) found that PGPR can increase P availability to plants through solubilizing insoluble phosphates and this improved $\mathrm{P}$ nutrition, which in turn increases the biological nitrogen fixation and availability of other nutrients for plants. El-Sherif et al. (2013) found that cyanobacteria can be incorporated into soil as organic matter and also as a source of enzymes as they produce acid and alkaline extracellular phosphatases that are active in solution or located in the peri-plasmatic space of the cell wall. Both biomass and exopolysaccharides incorporated into soil induce a growth promotion of other microorganisms and increase the activity of soil enzymes that participate in the liberation of nutrients required by plants. Harman (2000) suggested that Trichoderma spp. are opportunistic plant colonizers that affect plant growth by improving seed vigor and growth (Mastouri et al., 2012), promote seedling growth and change root structure and increase root activity in seedlings, possibly via the production or control of plant hormones (Kleifield and Chet, 1992 and Hermosa et al., 2012) and decomposing, recycling and utilizing soil nutrients (Shoresh et al., 2010 and Harman, 2011), improve the ability of plant photosynthesis 
(Huang et al., 2011) which consequently increased fruit yield (Shen et al., 2015 and Xiong et al., 2017).

\section{Conclusions}

Therefore, it is recommended to use the seeds treatment and foliar spraying of leaves with $N$. muscorum or A. oryzae mixed with $P$. fluorescens as safe biocontrol agents compared with the fungicide for controlling watermelon leaf spot and increasing its productivity under field conditions.

\section{References}

Abdel-Hafez, S.I.I.; Abo-Elyousr, K.A.M. and Abdel-Rahim, I.R. 2015. Fungicidal activity of extracellular products of cyanobacteria against Alternaria porri. Eur. J. Phycol., 50: 239-245.

Abedin, R.M.A. and Taha, H.M. 2008. Antibacterial and antifungal activity of cyanobacteria and green microalgae evaluation of medium components by Plackett-Burman design for antimicrobial activity of Spirulina platensis. J. Biochem., 3(1): 22-31.

Abhilash, P.C. and Singh, N. 2009. Pesticides use and application: an Indian scenario. J. Hazard. Mater., 165(1-3): 1-12.

Abo-Elyousr, K.A.M.; Abdel-Hafez, S.I.I and Abdel-Rahim, I.R. 2017. Control of Stemphylium leaf blight disease of onion and elevation of seed production using certain bioagents. Int. J. Plant Pathol., 8(1): 1-7.

Abo-Shady, A.M.; Al-Ghaffar, B.A.; Rahhal, M.M.H. and Abd-Elmonem, H.A. 2007. Biological control of faba bean pathogenic fungi by three cyanobacterial filtrates. Pakistan J. Biological Sci., 10(18): 3029-3038.

Aref, M.El. 2011. Response of Faba bean plants growth on saline soil to azolla, cyanobacteria and yeast extracts applied as foliar biofertilizers. Egypt. J. Biotechnol., 39: 32-41.

Asad, R. and Vafa, T. 2011. Nutrient uptake and yield of chickpea (Cicer arietinum L.) inoculated with plant growth promoting. Aust. J. crop sci. AJCS, 5(1): 44-48.

Asaka, O.; and Shoda, M. 1996. Biocontrol of Rhizoctonia solani damping-off of tomato with Bacillus subtilis RB14. Appl. Environ. Microbiol., 62: 4081-4085.

Bargabus, R.L.; Zidack, N.K.; Sherwood, J.W. and Jacobsen, B.J. 2004. Screening for the identification of potential biological control agents that induce systemic acquired resistance in sugar beet. Biol. Control, 30: 342-350.

Bharath, B.G.; Lokesh, S.; Rai, V.R.; Prakash, H.S.; Yashovarma, B. and Shetty, H.S. 2005. Role of foliar spray in the infection biology and management of

Egypt. J. Phytopathol., Vol. 47, No. 1 (2019) 
fungal diseases of watermelon (Citrullus lanatus (Thunb.) Matsum and Nakai). World J. Agricultural Sciences, 1(2): 105-108.

Compant, S.; Duffy, B.; Nowak, J.; Clement, C. and Barka, E.A. 2005. Use of plant growth-promoting bacteria for biocontrol of diseases: Principles, mechanisms of action, and future prospects. Appl. \& Environ. Microbiol., 71: 4951-4959.

De Caire, G.Z.; de Cano, M.S.; de Mule, M.C.Z. and de Halperin, D.R. 1990. Antimycotic products from cyanobacterium Nostoc muscorum against Rhizoctonia solani. Phyton-Buenos-Aires, 51:1-4.

Edwards, A.J.; Vinyard, B.T.; Wiley, E.R.; Brown, E.D.; Collins, J.K. and PerkinsVeazie, P. 2003. Consumption of watermelon juice increases plasma concentrations of lycopene and $\beta$-carotene in humans. J Nutr., 133: 1043-50.

Elad Y.; Chet, I. and Henis, Y. 1981. A selective medium for improving quantitative isolation of Trichoderma spp. from soil. Phytoparasitica, 9: 59-67.

Elad, Y. and Freeman, S. 2002. Biological control of fungal plant pathogens. In: Agricultural Applications. Springer, Berlin, Heidelberg. pp. 93-109.

El-Sherif, M.H.; El-Shahate, R.M. and Khalied, A.K. 2013. Improvement of growth and yield of faba bean by inoculation with azolla, cyanobacteria and rhizobia in saline sandy soil. J. Appl. Sci. Res., 9: 1675-1682.

Farag, M. F. 2018. Stemphylium botryosum and Cladosporium cucumerinum: A new challenge in watermelon production in Egypt. Plant Physiol Pathol., 6: pp

Fernando, W.G.D.; Nakkeera, S.; Zhang, Y. and Savchuk, S. 2007. Biological control of Sclerotinia sclerotiorum (Lib.) de Bary by Pseudomonas and Bacillus species on canola petals. Crop Prot., 26: 100-107.

Gnanamanickam, S.S.; Candole, B.L. and Mew, T.W. 1992. Influence of soil factors and cultural practice on biological control of sheath blight of rice with antagonistic bacteria. Plant and Soil, 144: 67-71.

Haiquan, H.; Meijuan, H.; Guosheng, F.; Xuefei, L.; Jihua, W.; Qing, D. and Qixiang, Z. 2013. Isolation and characterization of 1-aminocyclopropane-1carboxylate (ACC) deaminase-containing plant growth promoting rhizobacteria from carnation soil and roots. Afr. J. microbial., 7(50): 5664-5668.

Harman, G.E. 2000. Myths and dogmas of biocontrol Changes in perceptions derived from research on Trichoderma harzianum T22. Plant Dis., 84(4): 377393.

Harman, G.E. 2011. Trichoderma-Not just for biocontrol anymore. Phytoparasitica, 39: $103-108$. 
Hermosa, R.; Viterbo, A.; Chet, I. and Monte. E. 2012. Plant-beneficial effects of Trichoderma and of its genes. Microbiology 158: 17-25.

Höfte, M. and Bakker, P.A.H.M. 2007. Competition for iron and induced systemic resistance by siderophores of plant growth promoting rhizobacteria; Springer: Berlin/Heidelberg, Germany, pp. 121-133.

Howell, C.R. 2003. Mechanisms employed by Trichoderma species in the biological control of plant diseases: The history and evolution of current concepts. Plant Dis., 87: 4-10.

Huang, H.C. 1978. Gliocladium catenulatum: hyperparasite of Sclerotinia sclerotiorum and Fusarium sp. Can. J. Plant Pathol., 56: 2243-2246.

Huang, X.; Chen, L.; Ran, W.; Shen, Q. and Yang, X. 2011. Trichoderma harzianum strain SQR-T37 and its bio-organic fertilizer could control Rhizoctonia solani damping-off disease in cucumber seedlings mainly by the mycoparasitism. Appl. Microbiol. Biotechnol., 91: 741-755.

Hussein, M.A.M.; Hassan, M.H.A.; Allam, A.D.A. and Abo-Elyousr, K.A.M. 2007. Management of stemphylium blight of onion by using biological agents and resistance inducers. Egypt. J. Phytopathol., 35(1): 49-60.

Kapat, A.; Zimand, G. and Elad, Y. 1998. Effect of two isolates of Trichoderma harzianum on the activity of hydrolytic enzymes produced by Botrytis cinerea. Physiol. \& Mol. Plant Pathol., 52: 127-137.

King, E.O.; Ward, M.K. and Raney, D.E. 1954. Two simple media for the demonstration of pyocyanin and fluorescin. J. Lab. Clin. and Med., 44, 301-307.

Kleifeld, O. and Chet, I. 1992. Trichoderma-plant interaction and its effect on increased growth response. Plant Soil, 144: 267-272.

Korolev, N.; David, D.R. and Elad, Y. 2008. The role of phytohormones in basal resistance and Trichoderma-induced systemic resistance to Botrytis cinerea in Arabidopsis thaliana. Bio Control, 53: 667-683.

Lafka, T.I.; Sinanoglou, V. and Lazos, E.S. 2007. On the extraction and antioxidant activity of phenolic compounds from winery wastes. Food Chemistry. 104: 1206-1214.

Le, J.; Chuan, J.D.; Andy, H.L. and Colin, W.E. 2005. Do dietary lycopene and other carotenoids protect against prostate cancer International Journal of Cancer 113: $1010-1014$.

Mastouri, F.; Björkman, T. and Harman, G.E. 2012. Trichoderma harzianum enhances antioxidant defense of tomato seedling and resistance to water deficit. Mol. Plan. Microb. Interect., 25: 1264-1271.

Egypt. J. Phytopathol., Vol. 47, No. 1 (2019) 
Mathiyazhagan, S.; Kavitha, K.; Nakkeeran, S.; Chandrasekar, G.; Manian, K.; Renukadevi, P.; Krishnamoorthy, A.S. and Fernando, W.G.D. 2004. PGPR mediated management of stem blight of Phyllanthus amarus (Schum and Thonn) caused by Corynespora cassiicola (Berk and Curt) Wei. Arch. Phytopath. Plant Protection, 37: 183-199.

Meena, B. and Marimuthu, T. 2012. Effect of application methods of Pseudomonas fluorescens for the late leaf spot of groundnut management. J. Biopest., 5(1): 1417.

Patterson, G.M.L.; Larsen L.K. and Moore, R.E. 1994. Bioactive natural products from blue-green algae. J. Appl. Phycol., 6: 151-157.

Paul, D. and Sharma, Y.R. 2006. Antagonistic effects of metabolites of $P$. fluorescens strains on the different growth phases of Phytophthora capsici, root rot pathogen of black perpper (Piper nigrum L.). Archieves of Phytopathology and Plant Protection, 39: 113-118.

Perazzolli, M.; Dagostin, S.; Ferrari, A.; Elad, Y. and Pertot, I. 2008. Induction of systemic resistance against Plasmopara viticola in grapevine by Trichoderma harzianum T39 and benzothiadiazole. Biological Control, 47: 228-234.

Sandoval, C.; Terreros, V. and Schiappacasse, F. 2009. Control of Cladosporium echinulatum in carnation using bicarbonates and Trichoderma. Cien. Inv. Agr., 36(3): 487-498.

Singh, J. and Tripathi, N. 1999. Inhibition of storage fungi of blackgram (Vignamungo L.) by some essential oils. Flavour and Fragrance Journal, 14: 1-4.

Shali, A.; Rigi, G.; Pornour, M.; Ahmadian, G. 2017. Expression and secretion of cyan fluorescent protein (CFP) in B. subtilis using the chitinase promoter from Bacillus pumilus SG2. Iran. Biomed. J., 21: 240.

Shen, Z.; Ruan, Y.; Chao, X.; Zhang, J.; Li, R. and Shen, Q. 2015. Rhizosphere microbial community manipulated by 2 years of consecutive biofertilizer application associated with banana Fusarium wilt disease suppression. Biol. Fertil. Soils, 51: 553-562.

Shi, Y., Yang, L., Wang, X., Gao, Y., Liu, W. and Lou, K. 2012. Biocontrol of bacterial spot diseases of muskmelon using Paenibacillus polymyxa G-14. Afr. J. Biotechnol. 11: 16845-16851

Shindy, W.W. and Smith, Q.E. 1975. Identification of plant hormones from cotton ovules, Plant Physiol., 55, 550.

Shoresh, M.; Harman, G.E. and Mastouri, F. 2010. Induced systemic resistance and plant responses to fungal biocontrol agents. Annu. Rev. Phytopathol., 48: 21-43. 
Snedecor, G.W. and Cochran, W.G. 1989. "Statistical Methods".8th. ed. Iowa State Univ. Press, Ames, Iowa, USA, 251 pp.

Soria, S.; Alonso, R. and Bettucci, L. 2012. Endophytic bacteria from Pinustaeda L. as biocontrol agents of Fusarium circinatum Nirenberg \& O'Donnell. Chilean J. Agric. Res., 72(2): 281-284.

Wang, H.; Shi, Y.; Wang, D.; Yao, Z.; Wang, Y.; Liu, J.; Zhang, S. and Wang, A. 2018. A biocontrol strain of Bacillus subtilis WXCDD105 used to control tomato Botrytis cinerea and Cladosporium fulvum Cooke and promote the growth of seedlings. Int. J. Mol. Sci., 19: 1-17.

Xiao Y, L. I. and HX, Li C. 2013. Antifungal screening of endophytic fungi from Ginkgo biloba for discovery of potent anti-phytopathogenic fungicides. FEMS Microbiol Lett. 339:130-6.

Xiong, W.; Guo, S.; Jousset, A.; Zhao, Q. and Shen, Q. 2017. Bio-fertilizer application induces soil suppressiveness against Fusarium wilt disease by reshaping the soil microbiome. Soil Biol. Biochem., 114: 238-247.

Zeeshan, M.; Suhail, S.; Biswas, D.; Farooqui, A. and Arif, J.M. 2010. Screening of selected cyanobacterial strains for phycochemical compounds and biological activities in vitro. Biochemical and Cellular Archives, 10: 163-168.

Zegeye, E.D.; Santhanam, A.; Gorfu, D.; Tessera, M. and Kassa, B. 2011. Biocontrol activity of Trichoderma viride and Pseudomonas fluorescens against Phytophthorainfestans under greenhouse conditions. J. Agric. Technol., 7(6): 1589-1602.

Corresponding author: Farag, M.F.

E-mail: farag_mohamed@yahoo.com

(Received 13/01/2019;

in revised form 09/02/2019)

Egypt. J. Phytopathol., Vol. 47, No. 1 (2019) 
تاثير بعض الكائنات الحيوية على فطر كلادوسبوريوم ككمارينوم المسببً لتبقع الاوراق الكلادوسبوريومى التهي: تحد جديد في إنتاج البطيخ في مصرم.

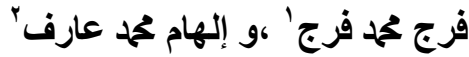

1ـ معهر بحوث أمراض النباتات ، مركز البحوث الزراعية ، الجيزة ، r- معهد بحوث الاراضى والمياة والبيئة ، مركز البحوث الزراعية ،

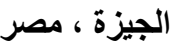

تم استخدام سبع عز لات من الكائنات الحيوية ، تر ايكودرما هاريزيانوم

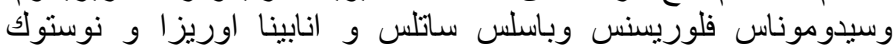

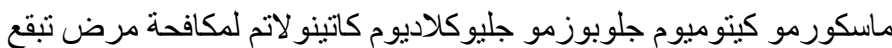

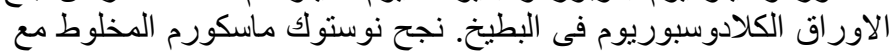

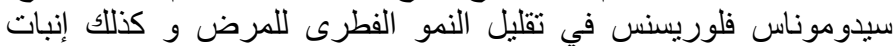

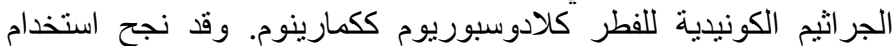

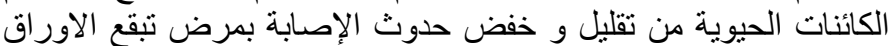

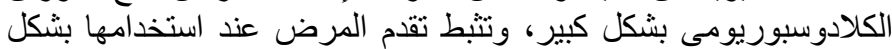

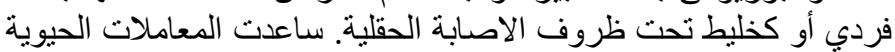

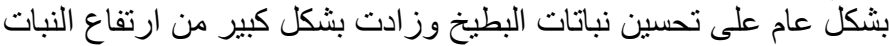

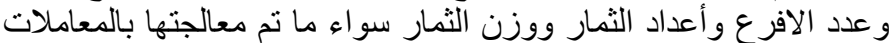
الحيوية المختبرة إما بصورة فردية أو في خليط مقارنة بالكنترول. 